\title{
FORM OF LAYING HENS EGGS IN THE FUNCTION OF DIFFERENT LAMPS USED IN PRODUCTION
}

Doi:http://dx.doi.org/10.1590/1809-4430-Eng.Agric.v37n5p848-854/2017

\section{DANILO F. PEREIRA ${ }^{1 *}$, BARTIRA DE O. TAVARES ${ }^{2}$, PRISCILLA A. B. MAC LEAN ${ }^{2}$}

${ }^{1 *}$ Corresponding author. São Paulo State University (UNESP), School of Sciences and Engineering, Tupã, SP, Brazil. E-mail: danilo@tupa.unesp.br

\begin{abstract}
Lighting, either in its intensity or in its luminous spectrum, affects the eggs quality. This study evaluated the effect of four lamps (sodium vapor lamp, mercury vapor lamp, fluorescent lamp and incandescent lamp) that have different luminous spectra in the form of commercial poultry eggs. For this, 60 laying hens of the same age were separated for 63 days in four aviaries with reduced and distorted scale. In each treatment, different lamps were installed which provided similar luminous intensities. At the end of the period, these eggs were taken as samples for the fluorescent, incandescent, mercury vapor and sodium vapor lamps. In this way, images were made of these eggs, using a camera installed on a fixed tripod on a flat table with black background. In a room with controlled lighting, ensuring the same distance and angle for all eggs. The Matlab ${ }^{\circledR}$ program was used to perform the image analysis, recording measurements of area, perimeter and minimum and maximum distances of the mass center of each egg. The measurements were grouped by treatment and the Tukey's test of averages was applied. The results showed that the eggs removed from the sodium vapor treatment presented a more elongated shape. It is concluded that the light spectrum of the lamps affects the shape of the eggs and this should be considered in the planning of lighting programs in aviaries.
\end{abstract}

KEYWORDS: environment, image analysis, precision animal production.

\section{INTRODUCTION}

Many studies report light as an important element for the health and behavior of poultry, and can affect them through interactions between physiological responses (Kristensen, 2006), behavioral (Macari, 2002) and productive characteristics (Navarro \& Lahti, 2014; Borille et al., 2015).

To evaluating the effects of the use of led technology on artificial lighting of Japanese quail, Jácome et al. (2012) tested four different lamps: Incandescent 15W and leds (blue, orange and white) and did not find significant differences ( $p>0.05$ ) for mean egg weight, shell weight and shell thickness between treatments.

However, Er et al. (2007) studied the effects of monochromatic lamps (red, blue, green and white) on laying hens from 38 to 52 weeks and found that the eggs laid by the hens in the blue lamps had their length diminished in relation to the other lamps and, under red light had their width diminished in relation to the other colors.

The egg size and its shape directly affect the quality of the shell. Altuntas \& Sekeroglu (2008) found that longer eggs than wide ones have a lower compression strength which could interfere with their transport and storage.

Egg shell provides protection against contamination by bacteria and other pathogens, so any deformity in the shell can disaggregate value and quality to the egg, causing damage to the production system (Hunton, 2002). The contamination of the eggs can occur horizontally through penetration in the shell and membranes of the shell by contaminating substances found in the poultry environment (Gantois et al., 2009).

\footnotetext{
${ }^{2}$ São Paulo State University (UNESP), School of Sciences and Engineering/ Tupã - SP, Brazil. 
In this research, the hypothesis is that the shape of the eggs is affected by the light source. The aim of this study was to test the effects on four types of commercial lamps on Brazilian aviaries in the laying eggs form.

\section{MATERIAL AND METHODS}

The experiment was carried out at the College of Sciences and Engineering of the Paulista State University "Júlio de Mesquita Filho" (UNESP), Tupã Campus - SP.

Four small-scale and distorted aviaries constructed on flat land were used with east-west orientation, as recommended by Nääs (1989) and Tinôco (2001). The east and west sides, constituting the transverse axis of the shed were enclosed with brickwork walls and the north and south sides, constituting the longitudinal axis were closed with wire screen for plant nursery. The floor inside the sheds is concrete, avoiding contamination of the soil by the animal stools. The sheds are covered with $6 \mathrm{~mm}$ thick asbestos cement tiles with $20 \mathrm{~cm}$ eaves being each shed with an internal area of $4.5 \mathrm{~m}^{2}(1.5 \mathrm{~m} \times 3.0 \mathrm{~m})$, with height of $1.4 \mathrm{~m}$.

In each aviary was installed a type of lighting: sodium vapor, mercury vapor, fluorescent and incandescent with different distribution of the light spectrum of each lamp (Figure 1).

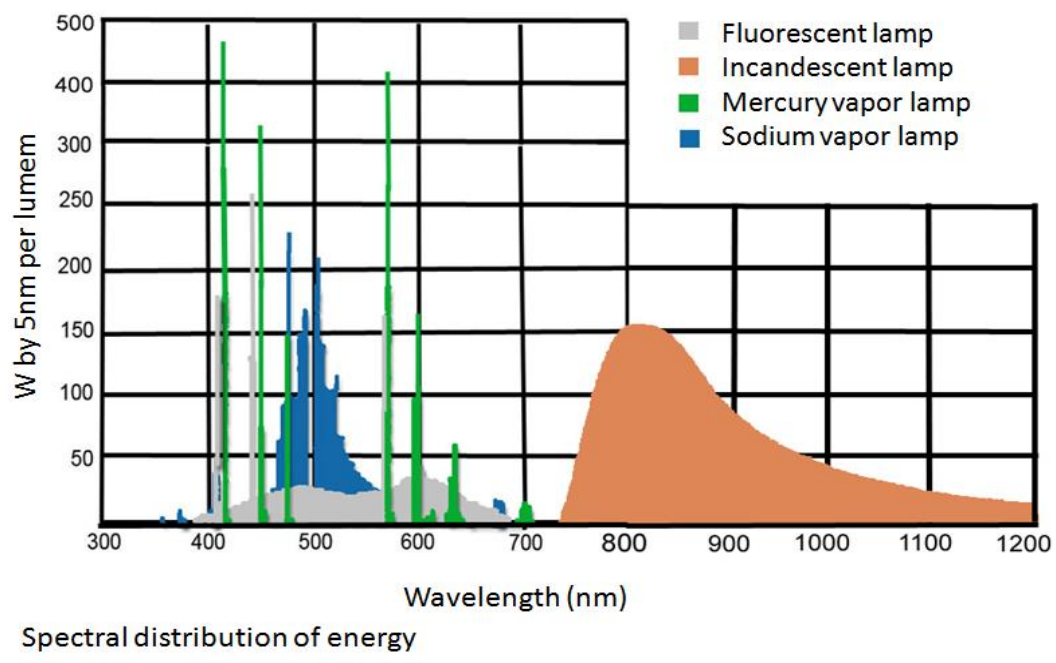

FIGURE 1. Spectral distribution of energy of the incandescent lamp, mercury vapor lamp, lamp vapor of sodium and fluorescent lamp.

It is observed that the chosen lamps have power peaks at different wavelengths. The sodium vapor lamp has power peak around the wavelength of $500 \mathrm{~nm}$. Mercury and fluorescent lamps have peaks distributed in the range of 400 to $700 \mathrm{~nm}$; however the fluorescent lamp has low and homogeneous power. The mercury vapor lamp has peaks at distinct wavelengths around the length of $450 \mathrm{~nm}$ and $600 \mathrm{~nm}$. The incandescent lamp has its peak around $800 \mathrm{~nm}$ and has a much more shifted distribution to the infrared region.

The potencies and the number of lamps installed in the sheds were calculated to provide the same illuminance isolating the influence of the light spectrum on the variable response of the egg shape.

In order to calculate the quantity of lamps that provided the same intensity luminous in the four sheds, it was used the Medium Lumens Method recommended by David \& Rossi (2010). For the calculation of the luminous flux was used the following equation:

$$
\Phi=\frac{E * S}{\mu * d}
$$

where,

$\phi$ - luminous flux (lumens); 
E - illuminance (lux);

$\mathrm{S}$ - area $\left(\mathrm{m}^{2}\right)$

$\mu$ - coefficient of use, and

d - depreciation factor or coefficient.

From the total luminous flux required was determined the number of lamps as follows:

$$
\mathbf{n}=\frac{\phi}{\emptyset}
$$

where,

$\mathrm{n}$ - number of lamps;

$\phi$ - luminous flux (lumens), and

$\varnothing$ - luminous flux of each lamp (lumens).

A mercury vapor lamp was installed in one of the sheds which is the lamp that emits the highest luminous intensity. In this way it was possible to calculate the luminous intensity that should be reached in the other sheds.

The calculated luminance for the mercury vapor lamp was 265 lux, and assuming that the other sheds should have compatible illuminance, the amount and power of lamps required was determined for each environment, the expected (calculated) luminous intensity, and the actual luminous intensity (measured) obtained using an LD-510 model Icel ${ }^{\circledR}$ luxmeter installed in the center of the shed was measured by a single measurement. The quantities and wattages of the adopted lamps in the experiment are described in Table 1.

TABLE 1. Number of lamps installed in each shed, calculated and measured illumination level.

\begin{tabular}{lccc}
\hline Light Source & Number of lamps & $\begin{array}{c}\text { Calculated Illuminance } \\
\text { (lux) }\end{array}$ & $\begin{array}{c}\text { Measured Illuminance } \\
\text { (lux) }\end{array}$ \\
\hline Mercury vapor & $1 \times 125 \mathrm{~W}$ & 265 & 243 \\
Sodium Value & $1 \times 75 \mathrm{~W}$ & 240 & 225 \\
Incandescent & $4 \times 100 \mathrm{~W}+1 \times 40 \mathrm{~W}$ & 246 & 277 \\
Fluorescent & $4 \times 20 \mathrm{~W}+1 \times 15 \mathrm{~W}$ & 249 & 247 \\
\hline
\end{tabular}

Sixty laying hens of DeKalb lineage, 52 weeks old were used at the beginning of the experiment, distributed in four sheds on a reduced and distorted scale. The hens were raised on new wood shaving bed.

The shed lamps were on at 5:00 a.m. and off at 9:00 p.m., totaling a photoperiod of 16 hours, reproducing the photoperiod supplied by the poultry farm that gave the hens to the experiment, with an average of 12 hours of natural light and four hours of artificial light. The activation of the lamps was performed automatically by timers installed in the lighting circuits of each shed.

All the hens received the same diet provided at will according to the management practiced by the original farm. The feed was replenished four times a day at 7:00 a.m., 12:00 a.m., 3:30 p.m. and 6:30 p.m., and the feeders were cleaned weekly, removing the excess and leftover feed. Water was supplied through four nipple-type nozzles in each treatment.

To confirm if the lamps used in this experiment affected the shape of the eggs, 70 eggs were collected after 63 days under the influence of the lamps. There were 16 eggs for fluorescent lamps, 21 eggs for incandescent lamps, 14 eggs for mercury vapor lamps and 19 eggs for sodium vapor lamps.

For the analysis of the shapes, images were made with a camera HDR-XR160 model; brand Sony ${ }^{\circledR}$, of 3.3 megapixels. To ensure that the photographs were always at the same distance and 
angle, the camera was installed on a tripod on a flat table. In the plane of the table was fixed a black color paper to emphasize the egg from the bottom of the image. Lighting was provided by a fluorescent lamp installed on the ceiling of the room (Figure 2).

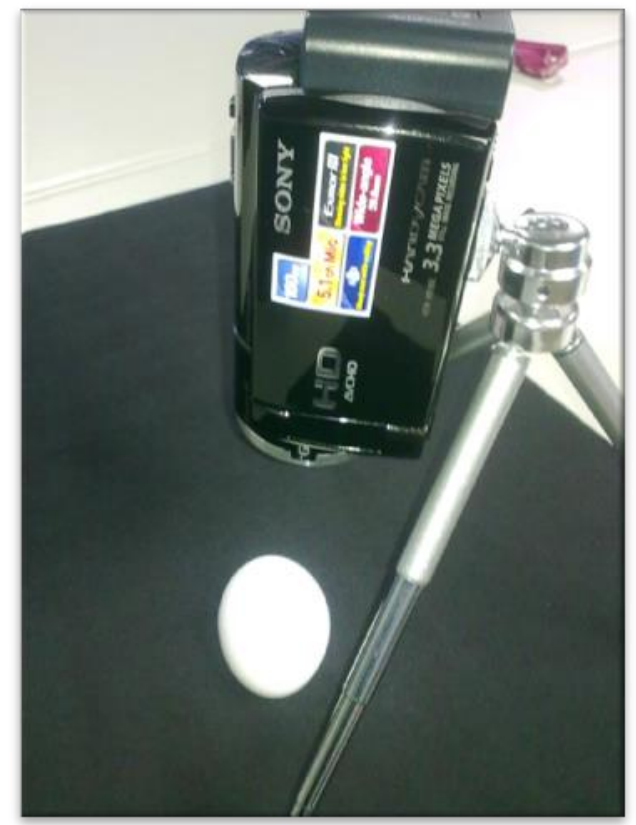

FIGURE 2. Camera installed on a black background, used to make the images of the eggs.

The images were analyzed in the Matlab ${ }^{\circledR}$ program. In order to highlight the egg of the image, an image of the background was subtracted under the same illumination condition from each image made for the eggs. After image processing, the measurements of area, perimeter and minimum and maximum distances from the center of mass to the perimeter of the eggs were recorded for each image (Figure 3).

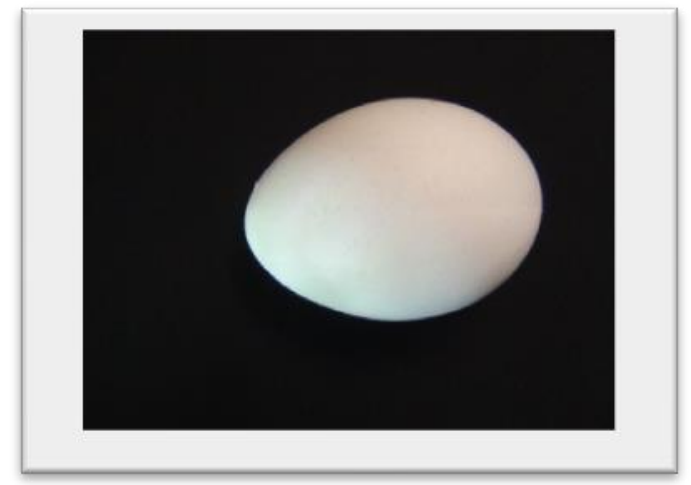

A

FIGURE 3. Image Processing containing an egg (A) and egg emphasis on extracting the metric measurements of the form (B).

From the metric measurements extracted from the images were calculated the coefficients of form in the following equations.

$$
\begin{aligned}
& C C=\frac{\text { perimeter }^{2}}{4 \times \pi \times \text { area }^{2}} \\
& C \max =\frac{\pi \times \text { dmax }^{2}}{\text { area }}
\end{aligned}
$$




$$
\text { Cmin }=\frac{\pi \times \operatorname{dmin}^{2}}{\text { area }}
$$

where,

dmin - minimum distance from the mass center of the shape to the perimeter;

$d m a x$ - maximum distance from the mass center of the shape to the perimeter;

$C C$ - coefficient of form;

Cmax - shape coefficient adapted for use of dmax, and

Cmin - adapted shape coefficient for the use of $d m i n$.

The results were compared using the Tukey test at 5\% probability.

\section{RESULTS AND DISCUSSION}

It was considered through evaluation and constant control in the environment that the variables external temperature, feed, water availability, shed characteristics and lighting level were similar for all treatments, so that differences in the observed egg shape were attributed to treatments light sources.

All the metric measurements extracted and the calculated form coefficients presented normal distribution by the Kolmogorov-Smirnov test (Table 2).

TABLE 2. Differences between the shapes of eggs laid by birds reared under incandescent lamps, compact fluorescent, sodium vapor and mercury vapor.

\begin{tabular}{lllll}
\hline \multirow{2}{*}{ Measures } & \multicolumn{3}{c}{ Treatments } \\
\cline { 2 - 5 } & Fluorescent & Incandescent & Mercury vapor & Sodium vapor \\
\hline Area $\left(10^{6} \mathrm{px}\right)$ & $1.12 \pm 0.06$ & $1.13 \pm 0.08$ & $1.10 \pm 0.05$ & $1.10 \pm 0.08$ \\
Perimeter $\left(10^{3} \mathrm{px}\right)$ & $5.42 \pm 0.18$ & $5.46 \pm 0.24$ & $5.37 \pm 0.15$ & $5.41 \pm 0.20$ \\
Dmax $\left(10^{2} \mathrm{px}\right)$ & $7.02 \pm 0.21$ & $7.07 \pm 0.28$ & $6.99 \pm 0.21$ & $7.13 \pm 0.26$ \\
Dmin $\left(10^{2} \mathrm{px}\right)$ & $5.16 \pm 0.18^{\mathrm{a}}$ & $5.20 \pm 0.19^{\mathrm{a}}$ & $5.11 \pm 0.12^{\mathrm{ab}}$ & $4.95 \pm 0.21^{\mathrm{b}}$ \\
$\mathrm{CC}$ & $2.08 \pm 0.06$ & $2.10 \pm 0.08$ & $2.08 \pm 0.06$ & $2.11 \pm 0.07$ \\
$\mathrm{Cmax}$ & $1.38 \pm 0.04^{\mathrm{b}}$ & $1.39 \pm 0.04^{\mathrm{b}}$ & $1.40 \pm 0.03^{\mathrm{b}}$ & $1.45 \pm 0.07^{\mathrm{a}}$ \\
Cmin & $0.74 \pm 0.03^{\mathrm{a}}$ & $0.75 \pm 0.02^{\mathrm{a}}$ & $0.75 \pm 0.02^{\mathrm{a}}$ & $0.70 \pm 0.03^{\mathrm{b}}$ \\
\hline
\end{tabular}

Area = plane image area of the egg in pixels; Perimeter = perimeter of the flat image of the egg in pixels; Dmax = maximum distance from the mass center of the flat image of the egg to the limit of the shape; Dmin = minimum distance from the mass center of the flat image of the egg to the limit of the shape; $C C=$ coefficient of form calculated from equation (1); Cmax = coefficient of form calculated from equation (2); Cmin = coefficient of form calculated from equation (3). Different letters indicate a significant difference between the lamps tested by the Tukey test at $5 \%$ probability.

It can be seen in Table 2 that the minimum distance from the perimeter to the mass center (dmin) of the eggs from hens subjected to the sodium vapor lamp treatment was significantly lower when compared to the eggs from the treatments of fluorescent and incandescent lamps. Considering the oval form of the eggs this means that the eggs placed in the treatments with sodium vapor lamps are more elongated than the eggs placed in the other treatments.

Considering that dmin is related to the width of the eggs and dmax with the length of the eggs, the larger the Cmin the wider the egg, and the larger the Cmax the longer the egg.

This difference in shape is confirmed by the significant differences $(\mathrm{P}<0.05)$ observed in the Cmax and Cmin form coefficients calculated for the eggs placed in the sodium vapor lamp treatment which emit waves with lengths of $550 \mathrm{~nm}$ to $600 \mathrm{~nm}$ when compared to other treatments.

It is interesting to note that the egg shell quality must be maintained and the standard shape can help to maintain the qualitative parameters, since the shell is its packaging, having to be clean, complete and without deformations (Ramos et al., 2010). The results presented in this study 
corroborate those found by (Er et al., 2007) that found more elongated eggs for hens created under red monochromatic light.

According to Altuntas \& Sekeroglu (2008) longer eggs than wider ones have a lower compressive strength, and this feature may interfere with the way eggs should be stored to avoid losses. Mainly losses influenced by the external environment to the egg such as the color of the raw yolk, specific gravity and even the sensorial evaluation, as described by Freitas et al. (2011), who compared the quality of eggs stored under refrigeration and natural environment, finding better parameters in refrigerated products.

Still, (Jácome et al., 2014), through a review of the available literature concluded that in most studies the artificial lighting programs influence egg production, but not egg quality parameters.

\section{CONCLUSIONS}

The shape of laying eggs was influenced by the different lamps in which the hens were exposed, and the sodium vapor lamp provided more elongated eggs. The light spectrum of the light source should be considered in the adequacy of the lighting system of laying poultry farms as this affects the quality of produced eggs.

\section{ACKNOWLEDGEMENTS}

We thank Recanto Alegre Poultry Farm located in the city of Tupã-SP, for giving the hens and the feed to the experiment. The CNPq by the Scientific Initiation scholarship and FAPESP process $n^{\circ} 2010$ / 19064-0 by the Research Grants awarded.

\section{REFERENCES}

Altuntas E, Sekeroglu A (2008) Effect of egg shape index on mechanical properties of chicken eggs. Journal of Food Engineering 85(4):606-612.

Borille R, Garcia RG, Nääs IA, Caldara FR, Santana MR (2015) Monochromatic light-emitting diode (LED) source in layers hens during the second production cycle. Revista Brasileira de Engenharia Agrícola e Ambiental 19(9):877-881.

David E, Rossi LA (2010) Diferentes tecnologias de iluminação para produção de mudas de crisântemo. Revista Brasileira de Engenharia Agrícola e Ambiental 14(3):261-266.

Er D, Wang Z, Cao J, Chen Y (2007) Effect monochromatic light on the egg quality of laying hens. The Journal of Applied Poultry Research 16(4):605-612.

Freitas LW, Lima ICde, Paz ICLA, Cavichiolo F (2011) Aspectos qualitativos de ovos comerciais submetidos a diferentes condições de armazenamento. Revista Agrarian 4(11):66-72.

Gantois I, Ducatelle R, Pasmans F, Haesebrouck F, Gast R, Humphrey TJ, Immerseel FV (2009) Mechanisms of egg contamination by Salmonella Enteritidis. FEMS Microbiology Reviews 33(4):718-738.

Hunton P (2002) Pesquisas sobre a estrutura e a qualidade da casca do ovo: um histórico. In: Conferência Apinco de Ciência e Tecnologia Avícola. Campinas, Fundação APINCO de Ciência e Tecnologia Avícolas, Anais... p21-24.

Jácome IMDT, Borille R, Rossi LA, Rizzotto DW, Becker JA, Sampaio CdeFR (2012)

Desempenho produtivo de codornas alojadas em diferentes sistemas de iluminação artificial. Archivos de zootecnia 61(235):449-456.

Jácome IMTD, Rossi LA, Borille R (2014) Influence of artificial lighting on the performance and egg quality of commercial layers: a review. Revista Brasileira de Ciência Avícola 16(4):337-344.

Kristensen HH (2006) The behaviour of broiler chickens in different light sources and illuminances. Applied Animal Behaviour Science 103:75-89. 
Macari M, Furlan RL, Gonzales E (2002) Fisiologia aviária aplicada a frangos de corte. Jaboticabal, FUNEP, 375p.

Nääs IA (1989) Princípios de conforto térmico na produção animal. São Paulo, Ícone. 183p.

Navarro JY, Lahti DC (2014) Light dulls and darkens bird eggs. PloS one 9(12):e116112.

Ramos KCBT, Camargo AM, Oliveira ECDde, Cedro TMM, Morenz MJF (2010) Avaliação da idade da poedeira, da temperatura de armazenamento e do tipo embalagem sobre a qualidade de ovos comerciais. Revista Ciências da Vida 30(2):55-66.

Tinôco IFF (2001) Avicultura industrial: novos conceitos de materiais, concepções e técnicas construtivas disponíveis para galpões avícolas brasileiros. Revista Brasileira de Ciência Avícola 3(1):1-26. 